\title{
Comparative Studies of the Sample Decomposition of Green and Roasted Coffee for Determination of Nutrients and Data Exploratory Analysis
}

\author{
Volnei R. Amorim Filho, ${ }^{*, a}$ Wagner L. Polito ${ }^{a}$ and José A. Gomes Neto ${ }^{b}$ \\ ${ }^{a}$ Instituto de Química de São Carlos, Universidade de São Paulo, CP 780, 13560-970 São Carlos-SP, Brazil \\ ${ }^{b}$ Instituto de Química, Universidade Estadual Paulista, CP 355, 14801-970 Araraquara-SP, Brazil
}

\begin{abstract}
Os teores de vários nutrientes foram determinados em 35 amostras de cafés verdes e torrados, por espectrometria de absorção atômica em chama ( $\mathrm{Ca}, \mathrm{Mg}, \mathrm{Fe}, \mathrm{Cu}, \mathrm{Mn}$ e $\mathrm{Zn}$ ), fotometria de emissão atômica em chama ( $\mathrm{Na}$ e K) e pelo método Kjeldahl $(\mathrm{N})$ após preparação das amostras por dois procedimentos de decomposição via úmida: $i$ ) sistema aberto (bloco digestor) e ii) sistema fechado (forno de microondas convencional com controle de pressão e temperatura). A exatidão dos procedimentos foi verificada analisando-se três materiais de referência certificados do National Institute of Standards and Technology (SRM 1573a Folha de Tomateiro; SRM 1547 Folha de Pessegueiro; SRM 1570a Espinafre). A análise dos dados após a aplicação do teste- $t$ mostrou que os resultados obtidos no procedimento que empregou decomposição assistida por microondas em frascos fechados foram mais exatos do que os obtidos por bloco digestor com frascos abertos no nível de $95 \%$ de confiança. Além da exatidão, outras características favoráveis encontradas foram menores valores de branco analíticos, menor consumo de reagentes e menor tempo de decomposição das amostras. Análises exploratórias dos dados empregando-se Análise por Componentes Principais (PCA) e Análise por Agrupamentos Hierárquicos (HCA) mostraram que os elementos $\mathrm{Na}, \mathrm{K}, \mathrm{Ca}, \mathrm{Cu}, \mathrm{Mg}$ e $\mathrm{Fe}$ foram os principais responsáveis na diferenciação das amostras de cafés verde e torrado.
\end{abstract}

The contents of some nutrients in 35 Brazilian green and roasted coffee samples were determined by flame atomic absorption spectrometry $(\mathrm{Ca}, \mathrm{Mg}, \mathrm{Fe}, \mathrm{Cu}, \mathrm{Mn}$, and $\mathrm{Zn}$ ), flame atomic emission photometry ( $\mathrm{Na}$ and $\mathrm{K}$ ) and Kjeldahl $(\mathrm{N})$ after preparing the samples by wet digestion procedures using $i$ ) a digester heating block and ii) a conventional microwave oven system with pressure and temperature control. The accuracy of the procedures was checked using three standard reference materials (National Institute of Standards and Technology, SRM 1573a Tomato Leaves, SRM 1547 Peach Leaves, SRM 1570a Trace Elements in Spinach). Analysis of data after application of $t$-test showed that results obtained by microwave-assisted digestion were more accurate than those obtained by block digester at $95 \%$ confidence level. Additionally to better accuracy, other favorable characteristics found were lower analytical blanks, lower reagent consumption, and shorter digestion time. Exploratory analysis of results using Principal Component Analysis (PCA) and Hierarchical Cluster Analysis (HCA) showed that $\mathrm{Na}, \mathrm{K}, \mathrm{Ca}, \mathrm{Cu}, \mathrm{Mg}$, and $\mathrm{Fe}$ were the principal elements to discriminate between green and roasted coffee samples.

Keywords: sample preparation, coffee, nutrients, exploratory analysis

\section{Introduction}

Coffee is an important commodity due to the high consumption of its beverage by people worldwide. ${ }^{1}$ Since the value of coffee beans is based on quality, producers and traders have been motivated to make use of extra tools in order to confirm the geographic origin of the coffee. ${ }^{2,3}$ In this context, inorganic chemical analyses of

*e-mail: volfilho@gmail.com green and roasted coffees may be used to assist the most demanding markets. ${ }^{1,2,4-8}$

Sample preparation still is a critical step in analytical sequence. Among aspects to be taken into consideration in a sample preparation procedure, the most important are the sample size, number and concentration of analytes, type of ashing, compatibility to the measurement equipment, required analytical blanks, time, reagent consumption and suitable precision and accuracy. ${ }^{9}$ 
There are several articles in the literature that describe the use of different pre-treatment for coffee solubilization involving wet digestion in a focused microwave system, ${ }^{1}$ digester heating block, ${ }^{2,5,6,8}$ PTFE (polytetrafluorethylene) pressure vessels, ${ }^{4}$ PTFE bombs ${ }^{8}$ and dry ashing. ${ }^{6}$ Most of these procedures present long waiting-time or use high amount of reagents for sample solubilization. Faster pretreatment procedures have been proposed by using tetramethylammonium hydroxide (TMAH) in digester heating block ( $10 \mathrm{~min} ; 80^{\circ} \mathrm{C} ; 500 \mu \mathrm{L}$ of $25 \% \mathrm{~m} / \mathrm{v}$ TMAH solution $+0.35 \mathrm{~g}$ soluble coffee $)^{7}$ or a focused microwave

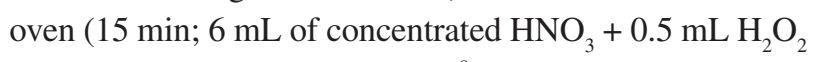
$30 \% \mathrm{~m} / \mathrm{m}+1 \mathrm{~g}$ soluble coffee $){ }^{8}$

Vanadium oxide $\left(\mathrm{V}_{2} \mathrm{O}_{5}\right)$ was effective as catalyst for wine decomposition in nitric acid for $\mathrm{Cd}$ and $\mathrm{Pb}$ determination. ${ }^{10}$ However, the use of this catalyst for the acid decomposition of green and roasted coffees in digester heating block for macro and micronutrients determination still requires investigation.

This paper reports on the evaluation of wet digestion procedures for the analysis of green and roasted coffees using open vessels in digester heating block and closed vessels heated in a conventional microwave oven system. Calcium, $\mathrm{Mg}, \mathrm{Fe}, \mathrm{Cu}, \mathrm{Mn}$, and $\mathrm{Zn}$ were determined by flame atomic absorption spectrometry, $\mathrm{Na}$ and $\mathrm{K}$ by flame atomic emission photometry, and $\mathrm{N}$ by Kjeldahl method. Multivariate exploratory analysis of analytical data using Principal Component Analysis (PCA) and Hierarchical Cluster Analysis (HCA) was applied to verify eventual similarity among green and roasted coffee samples.

\section{Experimental}

\section{Instruments and apparatus}

A Hitachi Z-8100 Polarized Zeeman Atomic Absorption Spectrometer (Tokio, Japan) was used to determine $\mathrm{Ca}, \mathrm{Mg}$, $\mathrm{Fe}, \mathrm{Cu}, \mathrm{Mn}$, and $\mathrm{Zn}$ according instrumental parameters described in Table 1. A Micronal B-262 flame atomic emission photometer (São Paulo, Brazil) was used to determine $\mathrm{Na}$ and $\mathrm{K}$, and a Tecnal TE-036 Kjeldahl apparatus (Piracicaba, Brazil) was used for $\mathrm{N}$ determination.

Coffee samples were digested by using a Perkin-ElmerAnton Paar Multiwave ${ }^{\mathrm{TM}}$ microwave oven (Graz, Austria) equipped with $50 \mathrm{~mL}$ TFM (Teflon Fluor Modified) vessels, and a Tecnal TE-040 digester heating block (Piracicaba, Brazil).

Coffee samples were powdered to particles $<50 \mu \mathrm{m}$ by employing a Spex 6800 cryogenic mill (Metuchen, USA). A Tecnal TE-648 Willye-type mill (Piracicaba, Brazil) were also used.

\section{Reagents, reference solutions and samples}

High purity water (resistivity $18.2 \mathrm{M} \Omega \mathrm{cm}$ ) obtained with a Millipore Rios $5^{\mathrm{TM}}$ reverse osmosis and a Millipore Milli- $\mathrm{Q}^{\mathrm{TM}}$ academic deionizer systems (Bedford, MA, USA) were used throughout the study.

All inorganic acids and reagents used in the sample digestion were of analytical grade $\left(\mathrm{HNO}_{3} 65 \% \mathrm{v} / \mathrm{v}-\right.$ Merck (Darmstadt, Germany), $\mathrm{H}_{2} \mathrm{SO}_{4} 98 \%$ v/v - Mallinckrodt (Phillipsburg, USA), and $\mathrm{H}_{2} \mathrm{O}_{2} 30 \% \mathrm{~m} / \mathrm{m}$ Merck (Darmstadt).

Stock standard solutions (1000 $\left.\mathrm{mg} \mathrm{L}^{-1}\right)$ of inorganic analytes were prepared by appropriate dilution of respective standard atomic absorption solutions (Normex ${ }^{\mathrm{TM}}$, Carlo Erba, Italy). For calibration, analytical solutions within the range of $0.25-2.0 \mathrm{mg} \mathrm{L}^{-1}(\mathrm{Ca}), 0.050-0.80 \mathrm{mg} \mathrm{L}^{-1}(\mathrm{Cu}$ and $\mathrm{Zn}$ ), 0.50 - $4.0 \mathrm{mg} \mathrm{L}^{-1}(\mathrm{Fe}), 0.50$ - $8.0 \mathrm{mg} \mathrm{L}^{-1}$ (K and $\left.\mathrm{Na}\right), 0.050$ $0.40 \mathrm{mg} \mathrm{L}^{-1}(\mathrm{Mg})$, and 0.20 - $2.0 \mathrm{mg} \mathrm{L}^{-1}(\mathrm{Mn})$ were prepared in $1 \% \mathrm{v} / \mathrm{v} \mathrm{HNO}_{3}$ by appropriate dilution of the stock solution.

For nitrogen determination by the Kjeldahl method, the combined catalyst was prepared by mixing $1 \mathrm{~g} \mathrm{Se}+$ $100 \mathrm{~g} \mathrm{Na}_{2} \mathrm{SO}_{4}+1 \mathrm{~g} \mathrm{CuSO}_{4}$. A mass of about $10 \mathrm{mg}$ of this mixture was used in each sample digestion vessel. Sodium hydroxide $10 \mathrm{~mol} \mathrm{~L}^{-1}$ (Merck, 99\% m/m), saturated solution of $\mathrm{H}_{3} \mathrm{BO}_{3}$ (Synth, $99.5 \% \mathrm{~m} / \mathrm{m}$ ), bromocresol green + methyl red indicator, and a standardized 0.1960 mol L-1 $\mathrm{H}_{2} \mathrm{SO}_{4}$ solution were also used.

Table 1. Instrumental parameters (Hitachi Z-8100 Spectrometer) for $\mathrm{Ca}, \mathrm{Mg}, \mathrm{Cu}, \mathrm{Fe}, \mathrm{Mn}$, and $\mathrm{Zn}$ determination in green and roasted coffee samples

\begin{tabular}{|c|c|c|c|c|c|c|}
\hline Instrumental Condition & $\mathrm{Ca}$ & $\mathrm{Mg}$ & $\mathrm{Cu}$ & $\mathrm{Fe}$ & $\mathrm{Mn}$ & $\mathrm{Zn}$ \\
\hline Radiation source & HCL & $\mathrm{HCL}$ & $\mathrm{HCL}$ & $\mathrm{HCL}$ & $\mathrm{HCL}$ & HCL \\
\hline Lamp current / (mA) & 7.5 & 7.5 & 7.5 & 15 & 7.5 & 5.0 \\
\hline Wavelength / (nm) & 422.7 & 285.2 & 324.8 & 248.3 & 279.6 & 213.9 \\
\hline Spectral resolution / (nm) & 1.3 & 1.3 & 1.3 & 0.2 & 0.4 & 1.3 \\
\hline Linear range / $\left(\mathrm{mg} \mathrm{L}^{-1}\right)$ & $0.5-2.0$ & $0.05-0.4$ & $0.05-0.8$ & $0.5-4.0$ & $0.2-2.0$ & $0.05-0.8$ \\
\hline \multicolumn{7}{|c|}{ Instrumental specific parameters } \\
\hline Background corrector & \multicolumn{6}{|c|}{ Zeeman effect } \\
\hline Measurement mode & \multicolumn{6}{|c|}{ Absorbance } \\
\hline Flame composition & \multicolumn{6}{|c|}{ Air/ Acetylene (oxidant) } \\
\hline
\end{tabular}


A mass of about $10 \mathrm{mg} \mathrm{V}_{2} \mathrm{O}_{5}$ catalyst was used in the digester heating block procedure. When necessary, samples were filtered (filter paper Framex, medium filtration) and transferred to a $25 \mathrm{~mL}$ volumetric flask and the volume made up with deionized water. A volume of $100 \mu \mathrm{L}$ of $5 \% \mathrm{~m} / \mathrm{v}$ lanthanum solution (Vetec, $99.99 \%$ $\mathrm{m} / \mathrm{m}$ ) was added in each digested sample before $\mathrm{Ca}$ and $\mathrm{Mg}$ determination to avoid chemical interferences caused mainly by silicates and phosphates.

Five commercial roasted coffee samples were purchased at the local market in Araraquara city (Brazil). Thirty samples of green coffee beans (Coffee arabica) were supplied by Brazilian cooperatives located in Minas Gerais and São Paulo States. The green coffee sample identified as PG 8 (Tables 3-6) is an unpulped ripe cherry from Patrocínio city, Minas Gerais State (Brazil).

Standard reference materials produced by National Institute of Standards and Technology (SRM 1573a Tomato Leaves, SRM 1547 Peach Leaves, and SRM 1570a Trace Elements in Spinach) were used to evaluate the accuracy of procedures.

\section{Sample preparation procedures and measurements}

A mass of green coffee was added to the polycarbonate container until approximately half of its total volume with the magnetic bar, which tightly closed, was adapted to the support and immersed in liquid nitrogen. Samples were pulverized by the impact between coffee beans and the magnetic bar submitted to an oscillating magnetic field of 20 impacts $\mathrm{s}^{-1}$. The cryogenic mill program consisted of 2 steps: 5 min of pre-cool and 2 min of mill.

One of the selected samples (sample number identification 1) was also ground using a Tecnal TE-648 Willye-type mill (Piracicaba, Brazil) without a previous sample freezing in order to verify eventual contamination by mill components. This sample was identified as number 2. Samples were oven-dried at $60{ }^{\circ} \mathrm{C}$ for $12 \mathrm{~h} .{ }^{11-13}$ The studied sample digestion procedures are described below.

\section{Digester heating block}

Masses of $c a .400 \mathrm{mg}$ of sample and $10 \mathrm{mg}$ of $\mathrm{V}_{2} \mathrm{O}_{5}$ catalyst were transferred to glass digester tubes, followed by $3 \mathrm{~mL}$ of concentrated $\mathrm{HNO}_{3}$ plus $2 \mathrm{~mL}$ of $30 \% \mathrm{~m} / \mathrm{m}$ $\mathrm{H}_{2} \mathrm{O}_{2}$. Tubes were heated at $180^{\circ} \mathrm{C}$ for $1 \mathrm{~h}$. The final digests were transferred to $25 \mathrm{~mL}$ volumetric flasks and the volumes were completed with deionized water. These solutions were directly used for $\mathrm{Cu}, \mathrm{Fe}, \mathrm{Mn}, \mathrm{Zn}$, and $\mathrm{Na}$ determination. For $\mathrm{Ca}$, a dilution factor of 10 was necessary. For $\mathrm{K}$ and $\mathrm{Mg}$, the solutions were diluted a hundred times. It is a good practice to filter some sample digests to avoid clogging of the nebulizer of the flame atomic absorption spectrometer.

\section{Microwave oven}

A mass of $c a .400 \mathrm{mg}$ of sample was transferred to TFM flasks followed by $3 \mathrm{~mL}$ of concentrated $\mathrm{HNO}_{3}$ plus $2 \mathrm{~mL}$ of $30 \% \mathrm{~m} / \mathrm{m} \mathrm{H}_{2} \mathrm{O}_{2}$. It is shown in Table 2 the optimized time-power program of the microwave oven for green and roasted coffee decomposition. The digests were transferred to $25 \mathrm{~mL}$ volumetric flasks and the volumes were completed with deionized water. Final solutions were further diluted as described above.

Table 2. Optimized time-power program of the microwave oven for green and roasted coffee decomposition

\begin{tabular}{llll}
\hline Step & Initial Power/(W) & Final Power/(W) & time/(min) \\
\hline 1 & 100 & 800 & 3 \\
2 & 800 & 800 & 5 \\
3 & 1000 & 1000 & 2 \\
4 & 0 & 0 & 8 \\
\hline
\end{tabular}

\section{Kjeldahl method}

Masses of $c a .0 .15 \mathrm{~g}$ of sample and $10 \mathrm{mg}$ of the combined catalyst $\left(\mathrm{Se}+\mathrm{Na}_{2} \mathrm{SO}_{4}+\mathrm{CuSO}_{4}\right.$ ) were transferred to glass digester flasks. Volumes of $5 \mathrm{~mL}$ of concentrated $\mathrm{H}_{2} \mathrm{SO}_{4}$ plus $1 \mathrm{~mL} 30 \% \mathrm{~m} / \mathrm{m} \mathrm{H}_{2} \mathrm{O}_{2}$ were added and the tubes were heated at $350{ }^{\circ} \mathrm{C}$ for about $210 \mathrm{~min}$. The resulting solutions were transferred to $25 \mathrm{~mL}$ volumetric flasks and the final volumes were completed with deionized water. Ammonia was distilled from a mixture containing $20 \mathrm{~mL}$ sample digest plus $20 \mathrm{~mL}$ of $10 \mathrm{~mol} \mathrm{~L}^{-1} \mathrm{NaOH}$ solution, and collected in a saturated boric acid solution. This final solution was titrated against standardized sulfuric acid solution.

\section{Treatment of data: paired t-test and multivariate analysis}

A paired $t$-test was applied to compare the results obtained with digester heating block and microwave oven procedures. It should be commented that the microwaveassisted digestion was elected as standard because it is a well-established tool to provide total digestion without analyte losses. ${ }^{14}$

The PCA and HCA analysis were applied to the data matrix, which consisted in concentration values obtained for the 9 studied analytes in 36 coffee samples. Two algorithms of the Pirouette program (InfoMetrix, Woodinville, WA, USA) version 2.02 were used throughout. The data were auto-scaled (pre-processing) due to the different magnitude orders of the studied variables. The Euclidean distance was used for measuring the similarity and as clustering methods incremental linkage. 


\section{Results and Discussion}

The results obtained for 10 samples with the two proposed procedures are depicted in Tables 3 ( $\mathrm{Na}$ and $\mathrm{K}$ ), $4(\mathrm{Ca}, \mathrm{Mg}$ and $\mathrm{N}), 5(\mathrm{Fe}$ and $\mathrm{Mn})$ and $6(\mathrm{Zn}$ and $\mathrm{Cu})$. Levels of nutrients obtained for coffee samples were in agreement with those reported in literature. ${ }^{1,2,4-8}$ All analyses were performed in triplicates.

Calibration curves with good linear correlation coefficients ( $r>0.999$ ) were consistently obtained for $\mathrm{Ca}$, $\mathrm{Mg}, \mathrm{Na}, \mathrm{K}, \mathrm{Cu}, \mathrm{Fe}, \mathrm{Mn}$, and $\mathrm{Zn}$ within the working range. The relative standard deviations for the analytes were always $\leq 2 \%$. The limits of detection (LOD $=3$ standard deviation of the blank / slope) in $\mu \mathrm{g} \mathrm{L}^{-1}$ were $29(\mathrm{Ca})$, $0.54(\mathrm{Mg}), 1.2(\mathrm{Na}), 1.3(\mathrm{~K}), 6.2(\mathrm{Cu}), 11(\mathrm{Fe}), 8.8(\mathrm{Mn})$, and $2.0(\mathrm{Zn})$.

Analysis of Table 3 suggests contamination by sodium since the samples digested in the open system presented higher levels of $\mathrm{Na}$ if compared with closed system. Systematic lower results for Ca (Table 4) were observed, which were attributed to formation of residues in the final digests. For $\mathrm{K}$ and $\mathrm{Mg}$ (Tables 3 and 4), the application of the paired $t$-test reveals that results obtained by digester block were in agreement with those obtained by microwave oven at $95 \%$ confidence level. It is interesting to note that the levels of $\mathrm{Na}, \mathrm{K}$ and $\mathrm{Ca}$ for sample PG 8 (unpulped ripe cherries) are higher than those for pulped ripe cherries, mainly for $\mathrm{K}$.
Table 3. Concentrations of $\mathrm{Na}$ and $\mathrm{K}$ in coffee samples

\begin{tabular}{lllll}
\hline & \multicolumn{2}{l}{$\mathrm{Na} /\left(\mathrm{mg} \mathrm{kg}^{-1}\right)^{\mathrm{b}}$} & \multicolumn{1}{l}{$\mathrm{K} /(\%)^{\mathrm{c}}$} & \\
Sample ID & Block & MW oven & Block & MW oven \\
\hline PG 5 & $47.7 \pm 1.7$ & $42.3 \pm 2.0$ & $1.52 \pm 0.04$ & $1.53 \pm 0.01$ \\
PG 6 & $67.0 \pm 2.8$ & $55.7 \pm 3.5$ & $1.52 \pm 0.02$ & $1.50 \pm 0.06$ \\
PG 7 & $74.7 \pm 7.7$ & $73.9 \pm 3.5$ & $1.44 \pm 0.05$ & $1.48 \pm 0.04$ \\
PG 8 & $75.5 \pm 2.6$ & $70.7 \pm 2.1$ & $2.10 \pm 0.04$ & $2.14 \pm 0.04$ \\
PG 11 & $59.5 \pm 1.9$ & $37.3 \pm 0.3$ & $1.84 \pm 0.02$ & $1.67 \pm 0.01$ \\
R 1 & $96.0 \pm 8.5$ & $67.7 \pm 3.7$ & $2.13 \pm 0.03$ & $1.96 \pm 0.05$ \\
R 2 & $90.6 \pm 2.8$ & $85.3 \pm 1.5$ & $2.79 \pm 0.05$ & $2.67 \pm 0.02$ \\
R 3 & $111.9 \pm 3.5$ & $77.3 \pm 1.7$ & $2.09 \pm 0.03$ & $2.11 \pm 0.04$ \\
R 4 & $84.5 \pm 6.0$ & $80.6 \pm 7.1$ & $2.27 \pm 0.05$ & $2.31 \pm 0.07$ \\
R 5 & $100.1 \pm 4.2$ & $70.2 \pm 4.6$ & $2.05 \pm 0.05$ & $2.04 \pm 0.02$ \\
\hline
\end{tabular}

${ }^{\text {a }}$ sample identification (PG - Patrocínio/MG green coffee; $\mathrm{R}$ - Commercial roasted coffee); ${ }^{\mathrm{b}, \mathrm{c}}$ concentration values found in literature for $\mathrm{Na}$ (10-174 $\left.\mathrm{mg} \mathrm{kg}^{-1}\right)$ and $\mathrm{K}(1.38-3.74 \%)$, respectively.

According Matos, it is possible to use in natura rinds and water from washing coffee process in agricultural areas in order to reduce coffee production costs. ${ }^{15}$ Taking into account Brazil production, this could save 430,000 tons of K per year, corresponding to around U\$ 120 millions spent with K-based fertilizers for $c a$. 2 millions cultivated hectares. The performance of the decomposition procedure using microwave oven was evaluated after analyzing 3 plant standard reference materials for $\mathrm{Na}, \mathrm{K}, \mathrm{Ca}$, and $\mathrm{Mg}$ determination. For the digester heating block, only $\mathrm{N}$ was determined. Results obtained for SRM's (Table 7) were in agreement with certified, non-certified, reference and informative

Table 4. Concentrations of $\mathrm{Ca}, \mathrm{Mg}$ and $\mathrm{N}$ in coffee samples

\begin{tabular}{|c|c|c|c|c|}
\hline Sample ID ${ }^{a}$ & $\begin{array}{l}\mathrm{Ca} /\left(\mathrm{mg} \mathrm{kg}^{-1}\right)^{\mathrm{b}} \\
\text { Block }\end{array}$ & MW oven & $\begin{array}{l}\mathrm{Mg} /\left(\mathrm{mg} \mathrm{kg}^{-1}\right. \\
\text { Block }\end{array}$ & MW oven \\
\hline PG 5 & $788 \pm 20$ & $1049 \pm 3$ & $2054 \pm 10$ & $2085 \pm 16$ \\
\hline PG 6 & $881 \pm 21$ & $1100 \pm 80$ & $2008 \pm 26$ & $2020 \pm 23$ \\
\hline PG 7 & $973 \pm 52$ & $1240 \pm 20$ & $1868 \pm 33$ & $1861 \pm 31$ \\
\hline PG 8 & $1870 \pm 40$ & $1710 \pm 40$ & $1598 \pm 11$ & $1609 \pm 13$ \\
\hline PG 11 & $885 \pm 2$ & $988 \pm 11$ & $1778 \pm 37$ & $1999 \pm 21$ \\
\hline R 1 & $1390 \pm 23$ & $1121 \pm 12$ & $2190 \pm 20$ & $2240 \pm 50$ \\
\hline R 2 & $1944 \pm 20$ & $1943 \pm 31$ & $1830 \pm 20$ & $1910 \pm 10$ \\
\hline R 3 & $1200 \pm 9$ & $1243 \pm 18$ & $2280 \pm 100$ & $2330 \pm 10$ \\
\hline R 4 & $1440 \pm 48$ & $1314 \pm 54$ & $2280 \pm 40$ & $2360 \pm 30$ \\
\hline R 5 & $1335 \pm 10$ & $1219 \pm 19$ & $2170 \pm 120$ & $2220 \pm 40$ \\
\hline Sample ID ${ }^{a}$ & \multicolumn{4}{|c|}{$\mathrm{N} /(\%)$ - Kjeldahl method ${ }^{\mathrm{d}}$} \\
\hline PG 5 & \multicolumn{4}{|l|}{$2.24 \pm 0.04$} \\
\hline PG 6 & \multicolumn{4}{|l|}{$1.95 \pm 0.01$} \\
\hline PG 7 & \multicolumn{4}{|l|}{$1.82 \pm 0.01$} \\
\hline PG 8 & \multicolumn{4}{|l|}{$1.92 \pm 0.02$} \\
\hline PG 11 & \multicolumn{4}{|l|}{$2.13 \pm 0.01$} \\
\hline R 1 & \multicolumn{4}{|l|}{$2.52 \pm 0.04$} \\
\hline R 2 & \multicolumn{4}{|l|}{$2.14 \pm 0.03$} \\
\hline R 3 & \multicolumn{4}{|l|}{$2.45 \pm 0.03$} \\
\hline R 4 & \multicolumn{4}{|l|}{$2.13 \pm 0.04$} \\
\hline R 5 & \multicolumn{4}{|l|}{$2.34 \pm 0.02$} \\
\hline
\end{tabular}

${ }^{a}$ sample identification (PG - Patrocínio/MG green coffee; R - Commercial roasted coffee), ${ }^{\mathrm{b}, \mathrm{c}, \mathrm{d}}$ concentration found in literature for Ca $\left(836-1310 \mathrm{mg} \mathrm{kg}{ }^{-1}\right), \mathrm{Mg}$ (1600-3000 $\left.\mathrm{mg} \mathrm{kg}^{-1}\right)$ and $\mathrm{N}(1.90-2.25 \%)$, respectively. 
values at a 95\% confidence level. Nevertheless, the found $\mathrm{N}$ concentration in all SRM's analyzed was lower than non-certified or reference values. According Fernandes et al. ${ }^{16}$ in the analyses of vegetable materials for total $\mathrm{N}$ determination aiming the determination of crude protein, the Kjeldahl method is the most used. However, the presence of non-protein N (4-9\%) in the nitrate form, make this procedure unsuitable, once the quantification of nitrogen in nitrate form is unfeasible due to the incomplete rupture of $\mathrm{N}-\mathrm{N}$ and $\mathrm{N}-\mathrm{O}$ chemical bonds during decomposition. The reduction of nitrates to ammonium form can be performed adding salicylic acid with $\mathrm{H}_{2} \mathrm{SO}_{4}$ to the samples in the decomposition procedure or by using the Dumas combustion method, which is also employed for total $\mathrm{N}$ determination. ${ }^{17}$ This method is able to quantify nitrate levels, is cheaper, faster and allows direct combustion of dried samples without the need of using reagents like $\mathrm{H}_{2} \mathrm{SO}_{4}, \mathrm{H}_{2} \mathrm{O}_{2}$, and catalyst.

The concentrations of micronutrients found in coffee samples are shown in Tables 5 and 6 . It can be seem that the digester block is susceptible to zinc contamination and it was ineffective for total $\mathrm{Fe}$ total solubilization from roasted coffees. These drawbacks were also observed in rocks and could be circumvented by using either a closed system to sample solubilization or higher amount of reagents and longer time. ${ }^{18}$ The Fe content in roasted coffee is typically higher than those found in green coffees (Table 5). It is interesting to note that the concentration value obtained for $\mathrm{Fe}$ in
Table 5. Concentrations of $\mathrm{Fe}$ and $\mathrm{Mn}$ in coffee samples

\begin{tabular}{lllll}
\hline & \multicolumn{2}{l}{$\mathrm{Fe} /\left(\mathrm{mg} \mathrm{kg}^{-1}\right)^{\mathrm{b}}$} & \multicolumn{2}{l}{$\mathrm{Mn} /\left(\mathrm{mg} \mathrm{kg}^{-1}\right)^{\mathrm{c}}$} \\
Sample ID & Block & MW oven & Block & MW oven \\
\hline PG 5 & $32.4 \pm 0.7$ & $37.0 \pm 0.8$ & $31.2 \pm 0.1$ & $31.0 \pm 0.4$ \\
PG 6 & $41.4 \pm 1.0$ & $42.2 \pm 1.1$ & $14.4 \pm 0.2$ & $14.7 \pm 0.1$ \\
PG 7 & $97.9 \pm 5.2$ & $107.5 \pm 4.7$ & $16.2 \pm 0.2$ & $13.4 \pm 0.3$ \\
PG 8 & $78.7 \pm 4.8$ & $107.0 \pm 3.4$ & $23.5 \pm 1.0$ & $23.6 \pm 0.1$ \\
PG 11 & $25.8 \pm 0.5$ & $26.8 \pm 0.7$ & $24.1 \pm 0.2$ & $24.0 \pm 0.4$ \\
R 1 & $51.4 \pm 2.1$ & $61.0 \pm 0.2$ & $19.8 \pm 0.9$ & $22.0 \pm 1.0$ \\
R 2 & $192.0 \pm 5.2$ & $282.3 \pm 15.2$ & $26.4 \pm 0.4$ & $27.4 \pm 0.1$ \\
R 3 & $51.7 \pm 1.7$ & $69.5 \pm 1.6$ & $26.2 \pm 1.3$ & $27.9 \pm 0.1$ \\
R 4 & $154.2 \pm 5.6$ & $233.7 \pm 2.2$ & $31.7 \pm 1.6$ & $36.0 \pm 0.6$ \\
R 5 & $66.7 \pm 1.8$ & $85.0 \pm 8.5$ & $23.9 \pm 0.2$ & $24.5 \pm 0.5$ \\
\hline
\end{tabular}

a sample identification (PG - Patrocínio/MG green coffee; R - Commercial roasted coffee), , ${ }^{\mathrm{b} c \mathrm{c}}$ concentration values found in literature for Fe (25.0$\left.140 \mathrm{mg} \mathrm{kg}^{-1}\right)$ and $\mathrm{Mn}\left(14.0-60.0 \mathrm{mg} \mathrm{kg}^{-1}\right)$, respectively.

Table 6. Concentrations of $\mathrm{Zn}$ and $\mathrm{Cu}$ in coffee samples

\begin{tabular}{|c|c|c|c|c|}
\hline \multirow[b]{2}{*}{ Sample ID ${ }^{\mathrm{a}}$} & \multicolumn{2}{|c|}{$\mathrm{Zn} /\left(\mathrm{mg} \mathrm{kg}^{-1}\right)^{\mathrm{b}}$} & \multicolumn{2}{|c|}{$\mathrm{Cu} /\left(\mathrm{mg} \mathrm{kg}^{-1}\right)^{\mathrm{c}}$} \\
\hline & Block & MW oven & Block & MW oven \\
\hline PG 5 & $9.34 \pm 0.10$ & $6.17 \pm 0.07$ & $14.9 \pm 0.3$ & $14.3 \pm 0.3$ \\
\hline PG 6 & $16.8 \pm 0.2$ & $6.73 \pm 0.90$ & $14.0 \pm 0.2$ & $14.5 \pm 0.3$ \\
\hline PG 7 & $9.67 \pm 0.24$ & $7.81 \pm 0.37$ & $14.0 \pm 0.7$ & $14.3 \pm 0.6$ \\
\hline PG 8 & $13.6 \pm 0.6$ & $5.89 \pm 0.41$ & $16.0 \pm 0.4$ & $16.7 \pm 0.4$ \\
\hline PG 11 & $4.55 \pm 0.03$ & $4.24 \pm 0.06$ & $12.7 \pm 0.2$ & $13.1 \pm 0.1$ \\
\hline R 1 & $10.8 \pm 0.2$ & $7.14 \pm 0.33$ & $13.3 \pm 0.2$ & $12.5 \pm 0.5$ \\
\hline $\mathrm{R} 2$ & $12.8 \pm 0.5$ & $7.08 \pm 0.34$ & $18.8 \pm 0.3$ & $18.7 \pm 0.3$ \\
\hline R 3 & $5.23 \pm 0.44$ & $4.65 \pm 0.42$ & $14.5 \pm 0.3$ & $14.8 \pm 0.4$ \\
\hline R 4 & $15.5 \pm 0.3$ & $6.17 \pm 0.02$ & $18.1 \pm 0.2$ & $17.1 \pm 0.3$ \\
\hline R 5 & $4.80 \pm 0.32$ & $5.31 \pm 0.37$ & $14.7 \pm 0.2$ & $13.7 \pm 0.3$ \\
\hline
\end{tabular}

${ }^{\mathrm{a}}$ sample identification (PG - Patrocínio/MG green coffee; $\mathrm{R}$ - Commercial roasted coffee), , b, concentration values found in literature for $\mathrm{Zn}$ (3.00$\left.10.0 \mathrm{mg} \mathrm{kg}^{-1}\right)$ and $\mathrm{Cu}\left(1.00-33.0 \mathrm{mg} \mathrm{kg}^{-1}\right)$, respectively.

Table 7. Concentration values determined for $\mathrm{Na}, \mathrm{K}, \mathrm{N}, \mathrm{Ca}, \mathrm{Mg}, \mathrm{Fe}, \mathrm{Mn}, \mathrm{Zn}$ and $\mathrm{Cu}$ in three plant standard reference materials

\begin{tabular}{|c|c|c|c|c|}
\hline Elements & SRM & $\begin{array}{l}\text { SRM } 1573 \\
\text { Tomato leaves }\end{array}$ & $\begin{array}{l}\text { SRM } 1547 \\
\text { Peach leaves }\end{array}$ & $\begin{array}{l}\text { SRM } 1570 \\
\text { Spinach }\end{array}$ \\
\hline $\mathrm{Na} /\left(\mathrm{mg} \mathrm{kg}^{-1}\right)$ & & $\begin{array}{l}136 \pm 4(\mathrm{C}) \\
140.8 \pm 0.2(\mathrm{O})\end{array}$ & $\begin{array}{l}24 \pm 2(\mathrm{C}) \\
25.8 \pm 0.3(\mathrm{O})\end{array}$ & $\begin{array}{l}18180 \pm 43(\mathrm{C}) \\
17709 \pm 185(\mathrm{O})\end{array}$ \\
\hline $\mathrm{K} /(\%)$ & & $\begin{array}{l}2.70 \pm 0.05(\mathrm{C}) \\
2.67 \pm 0.02(\mathrm{O})\end{array}$ & $\begin{array}{l}2.43 \pm 0.03(\mathrm{C}) \\
2.30 \pm 0.05(\mathrm{O})\end{array}$ & $\begin{array}{l}2.90 \pm 0.05(\mathrm{C}) \\
2.72 \pm 0.06(\mathrm{O})\end{array}$ \\
\hline $\mathrm{N} /(\%)$ & & $\begin{array}{l}2.92(\mathrm{NC}) \\
2.73 \pm 0.003(\mathrm{O})\end{array}$ & $\begin{array}{l}2.96(\mathrm{NC}) \\
2.55 \pm 0.004(\mathrm{O})\end{array}$ & $\begin{array}{l}5.68 \pm 0.13(\mathrm{RV}) \\
5.19 \pm 0.01(\mathrm{O})\end{array}$ \\
\hline $\mathrm{Ca} /(\%)$ & & $\begin{array}{l}5.05 \pm 0.09(\mathrm{NC}) \\
5.06 \pm 0.13(\mathrm{O})\end{array}$ & $\begin{array}{l}1.56 \pm 0.02(\mathrm{C}) \\
1.57 \pm 0.01(\mathrm{O})\end{array}$ & $\begin{array}{l}1.527 \pm 0.041(\mathrm{C}) \\
1.440 \pm 0.013(\mathrm{O})\end{array}$ \\
\hline $\mathrm{Mg} /(\%)$ & & $\begin{array}{l}1.2(\mathrm{NC}) \\
1.20 \pm 0.015(\mathrm{O})\end{array}$ & $\begin{array}{l}0.432 \pm 0.008(\mathrm{C}) \\
0.433 \pm 0.003(\mathrm{O})\end{array}$ & $\begin{array}{l}0.89 \text { (IV) } \\
0.90 \pm 0.011(\mathrm{O})\end{array}$ \\
\hline $\mathrm{Fe} /\left(\mathrm{mg} \mathrm{kg}^{-1}\right)$ & & $\begin{array}{l}368 \pm 7(\mathrm{C}) \\
357 \pm 2(\mathrm{O})\end{array}$ & $\begin{array}{l}218 \pm 14(\mathrm{C}) \\
195.9 \pm 9.8(\mathrm{O})\end{array}$ & $\begin{array}{l}(\mathrm{NS}) \\
235.5 \pm 1.7(\mathrm{O})\end{array}$ \\
\hline $\mathrm{Mn} /\left(\mathrm{mg} \mathrm{kg}^{-1}\right)$ & & $\begin{array}{l}246 \pm 8(\mathrm{C}) \\
247 \pm 3(\mathrm{O})\end{array}$ & $\begin{array}{l}98 \pm 3(\mathrm{C}) \\
88.6 \pm 0.3(\mathrm{O})\end{array}$ & $\begin{array}{l}75.9 \pm 1.9(\mathrm{C}) \\
71.6 \pm 0.3(\mathrm{O})\end{array}$ \\
\hline $\mathrm{Zn} /\left(\mathrm{mg} \mathrm{kg}^{-1}\right)$ & & $\begin{array}{l}30.9 \pm 0.7(\mathrm{C}) \\
30.3 \pm 0.2(\mathrm{O})\end{array}$ & $\begin{array}{l}17.9 \pm 0.4(\mathrm{C}) \\
16.6 \pm 0.1(\mathrm{O})\end{array}$ & $\begin{array}{l}82 \pm 3(\mathrm{C}) \\
76 \pm 1(\mathrm{O})\end{array}$ \\
\hline $\mathrm{Cu} /\left(\mathrm{mg} \mathrm{kg}^{-1}\right)$ & & $\begin{array}{l}4.70 \pm 0.14(\mathrm{C}) \\
4.45 \pm 0.14(\mathrm{O})\end{array}$ & $\begin{array}{l}3.7 \pm 0.4(\mathrm{C}) \\
3.9 \pm 0.2(\mathrm{O})\end{array}$ & $\begin{array}{l}12.2 \pm 0.6(\mathrm{C}) \\
12.2 \pm 0.2(\mathrm{O})\end{array}$ \\
\hline
\end{tabular}

(C) - certified concentration value; $(\mathrm{O})$ - obtained concentration value; $(\mathrm{NC})$ - non-certified concentration value; (RV) - reference concentration value; (IV) - information concentration value; (NS) - not specified concentration value. 
sample PG 8 (unpulped ripe cherries) is higher than those for pulped ripe cherries (green coffee samples identified as PG 5, PG 6, and PG 11).

The difference between the concentrations of $\mathrm{Fe}$ obtained for a green coffee ground by cryogenic mill (sample PG 6) and Willye-type steel mill (sample PG 7) can be attributed to abrasion of inner parts of the Willyetype mill. Contamination by $\mathrm{Fe}$ and $\mathrm{Cr}$ was also observed for plant material ground in steel mill due to the releasing of these elements to the samples by the overheating of the mill. ${ }^{19}$ The obtained values for $\mathrm{Cu}, \mathrm{Fe}, \mathrm{Mn}$ and $\mathrm{Zn}$ in three SRM's were in agreement with certified values at 95\% confidence level (see Table 7).

The most important commercial species of coffee are Coffee arabica and Coffee canephora, usually known as arabica and robusta varieties, respectively. Coffee robusta is more used in production of soluble coffee, and the solids extraction rate in fabrication process of this coffee is higher than when using Arabica. ${ }^{20}$ This can explain differences for some macro and micronutrients levels found in green (arabica) and roasted coffee samples (probably with the addition of robusta), in addition to factors involved in the industrial process of roasted coffee. ${ }^{1}$

The PCA and HCA analysis were applied after autoscaling data due to the different magnitude orders of the concentrations. $^{21,22}$ The PCA showed that with only six principal components it is possible to describe $91.4 \%$ of data, being $32.3 \%$ of the total variance described by the first principal component (PC1), $18.6 \%$ by $\mathrm{PC} 2,14.8 \%$ by PC $3,10.7 \%$ by PC4, $10.0 \%$ by PC 5 and $5.0 \%$ by PC6. The simultaneous analysis of the scores and loadings graphics (Figures 1a and 1b) show that PC1 separates the samples in relation to $\mathrm{Ca}, \mathrm{K}$, and $\mathrm{Na}$ concentrations, while PC3 separates the samples in relation to $\mathrm{Cu}, \mathrm{Fe}$ and $\mathrm{Mg}$ concentrations. The commercial roasted coffee samples (samples R1-R5) presented higher concentrations of $\mathrm{Mg}$ (samples R1, R3, and R5), Na, Ca, and K (samples R2 and R4). It should be commented that samples R2 and R4

(a)
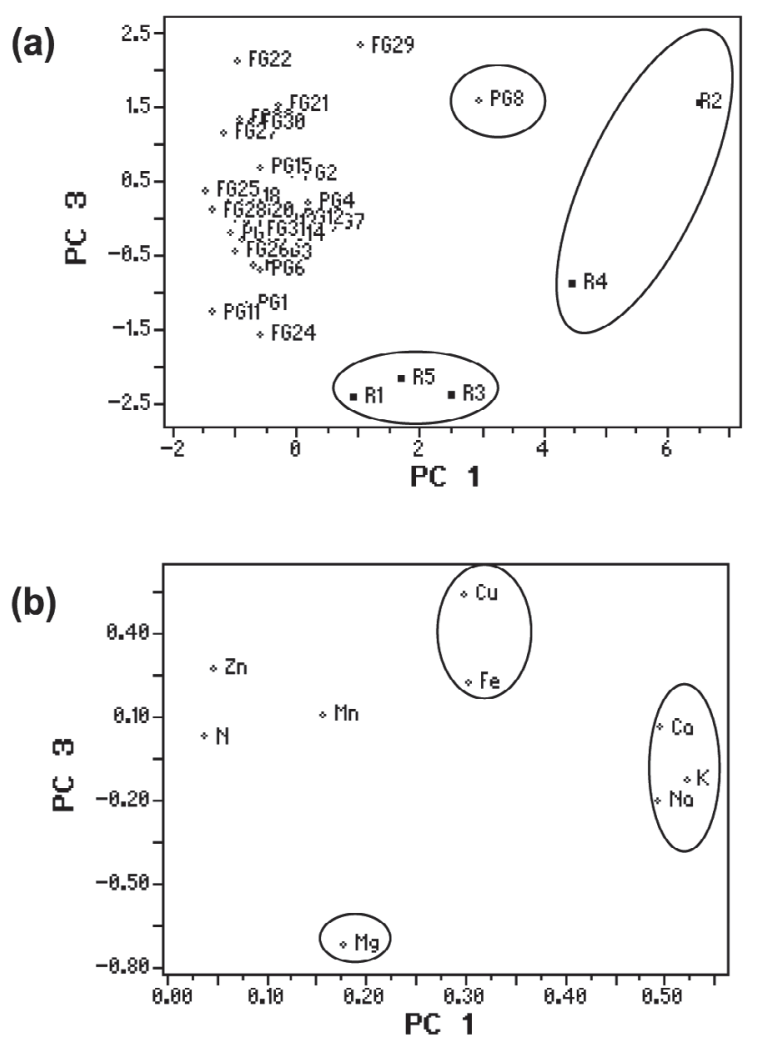

Figure 1. Principal component analysis $(\mathrm{PC} 1 \times \mathrm{PC} 3)$ showing Scores (a) and Loadings (b) graphics.

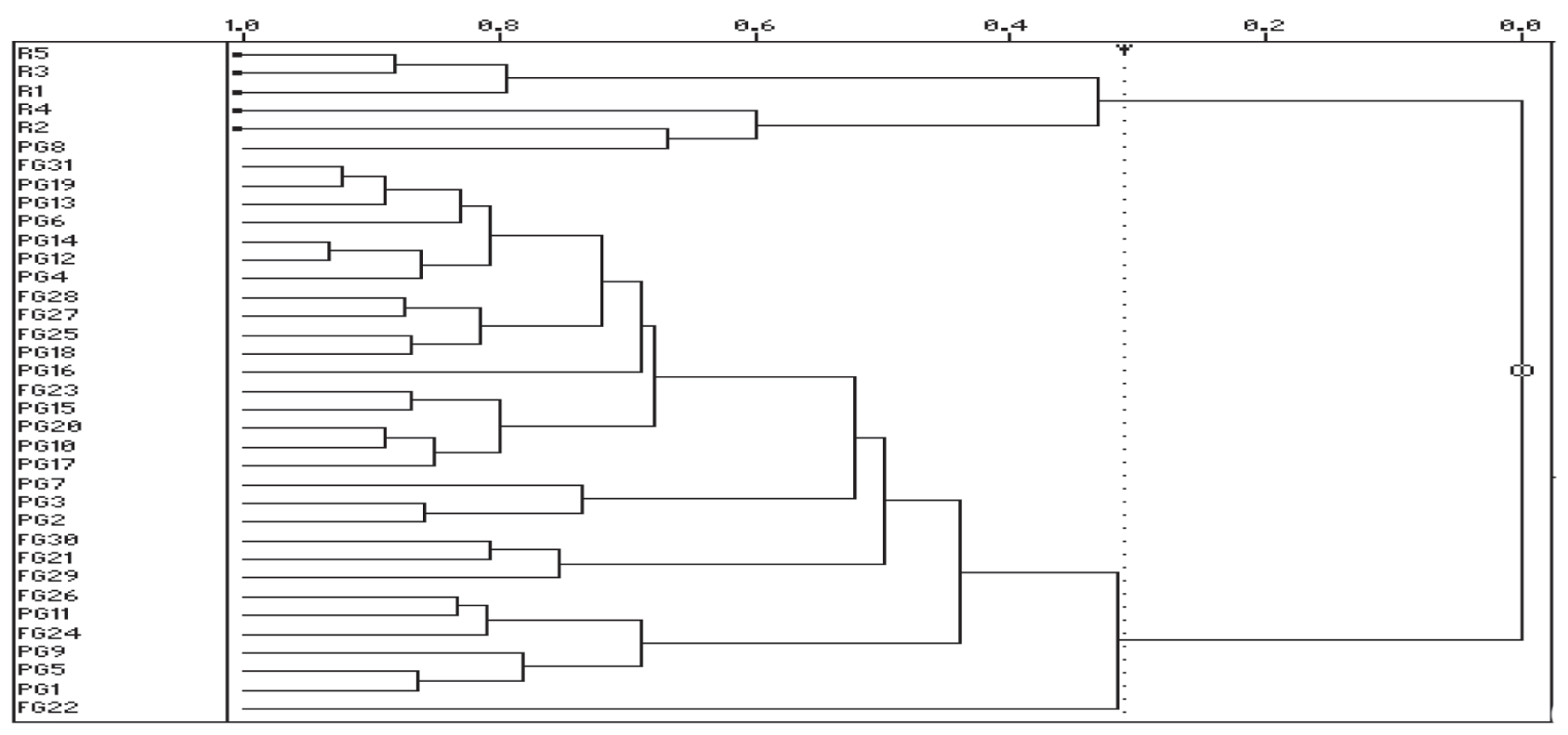

Figure 2. Hierarchical cluster analysis. Similarity $=0.306$. 
are displaced due to their high iron concentrations (Table 5). Sample PG 8 (unpulped ripe cherries) was displaced towards to $\mathrm{Fe}, \mathrm{Na}, \mathrm{Ca}$, and $\mathrm{K}$, confirming the nutritional value of the coffee rinds in manuring applications and production of animal foodstuffs. The HCA (Figure 2) confirmed similarities existing among elemental levels and PCA results.

\section{Conclusions}

The $t$-test showed that results obtained by digester heating block procedure were in agreement at 95\% confidence level with those obtained by the microwave oven procedure for $\mathrm{Cu}, \mathrm{Mn}, \mathrm{K}$, and $\mathrm{Mg}$. Digester heating block system is susceptible to $\mathrm{Na}$ and $\mathrm{Zn}$ contamination. On the other hand, this system led to lower $\mathrm{Ca}$ concentration for most samples. Both procedures can be used for determination of Fe in green coffee samples. For roasted coffee, only microwave oven was effective. The Willye-type mill contaminated the coffee samples with $\mathrm{Fe}$. High quantities of $\mathrm{Na}, \mathrm{Ca}$, $\mathrm{Fe}$, and $\mathrm{K}$ were found in coffee rinds. These can be used as a good source of inorganic nutrients $(\mathrm{Ca}, \mathrm{Fe}$, and $\mathrm{K}$ ) in fertilizers and animal feeding.

The use of Principal Component Analysis (PCA) and Hierarchical Cluster Analysis (HCA) applied to the inorganic composition of coffee allowed to observe similarities and discrepancies between green and roasted coffees. In general, roasted coffees present higher levels of $\mathrm{Na}, \mathrm{K}, \mathrm{Ca}, \mathrm{Mg}$, and $\mathrm{Fe}$. The main elements responsible for the discrimination between green and roasted coffee samples were $\mathrm{Na}, \mathrm{K}, \mathrm{Ca}, \mathrm{Mg}, \mathrm{Fe}$, and $\mathrm{Cu}$.

\section{Acknowledgments}

The authors thank the Fundação de Amparo à Pesquisa do Estado de São Paulo (FAPESP) for financially supporting this work and are also thankful the Coordenação de Aperfeiçoamento de Pessoal de Nível Superior (CAPES) for fellowships to V.R.A.F. and the Conselho Nacional de Desenvolvimento Científico e Tecnológico (CNPq) for researchship to J.A.G.N.

\section{Supplementary Information}

The results obtained for the 35 analyzed samples are available free of charge at http://jbcs.sbq.org.br, as PDF file.

\section{References}

1. Santos, E. J. dos; Oliveira, E. de; J. Food Comp. Anal. 2001, 14, 523 .

2. Anderson, K. A.; Smith, B. W.; J. Agric. Food Chem. 2002, 50, 2068.

3. Boas, B. M. V.; Licciardi, R.; Morais, A. R.; Carvalho, V. D.; Rev. Cienc. Agrotecnol. 2001, 25, 1169.

4. Krivan, V.; Barth, P.; Morales, A. F.; Mikrochim. Acta 1993, 110, 217.

5. Martín, M. J.; Pablos, F.; González, A. G.; Anal. Chim. Acta 1998, 358, 177.

6. Morgano, M. A.; Pauluci, L. F.; Mantovani, D. M. B.; Mory, E. E. M.; Rev. Cienc. Agrotecnol. 2002, 22, 19.

7. Ribeiro, A. S.; Moretto, A. L.; Arruda, M. A. Z.; Cadore, S.; Microchim. Acta 2003, 141, 149.

8. Santos, E. J. dos; Oliveira, E. de; Braz. Arch. Biol. Technol. 1997, 40, 632.

9. Oliveira, E. de; J. Braz. Chem. Soc. 2003, 14, 174.

10. Freschi, G. P. G.; Dakuzaku, C. S.; Moraes, M.; Nóbrega, J. A.; Gomes Neto, J. A.; Spectrochim. Acta B 2001, 56, 1987.

11. Munter, R. C.; Halverson, T. L.; Anderson, R. D.; Commun. Soil Sci. Plant Anal. 1984, 15, 1265.

12. Correia, P. R. M.; Oliveira, E. de; Oliveira, P. V.; Anal. Chim. Acta 2000, 405, 205.

13. Santos Jr., D.; Barbosa Jr., F.; Tomazelli, A. C.; Krug, F. J.; Nóbrega, J. A.; Arruda, M. A. Z.; Anal. Bioanal. Chem. 2002, 373, 183.

14. Kingston, H. M.; Jassie, L. B.; Introduction to Microwave Sample Preparation - Theory and Practice. ACS Professional Reference Book: Washington D.C., 1998.

15. Matos, A. T.; Campo \& Negócios Revista 2003, July, 41.

16. Fernandes, A. P.; Carrilho, E. N. V.; Souza, G. B.; Nogueira, A. R. A.; Nóbrega, J. A.; Abstracts of the $13^{\underline{0}}$ Encontro Nacional de Química Analítica / 1ํ Congresso Ibero-Americano de Química Analítica, Universidade Federal Fluminense, NiteróiRJ, Brazil, 2005, p.49.

17. Krug, F. J.; III Workshop sobre preparo de amostras, Universidade Federal de São Carlos, São Carlos-SP, 2000, p. 149.

18. Amorim Filho, V. R.; Polito, W. L.; Gomes Neto, J. A.; At. Spectrosc. 2004, 25, 233.

19. Markert, B.; Sci. Total Environ. 1995, 176, 45.

20. Ukers, W. H. In All About Coffee; $2^{\text {nd }}$ ed., Ukers, W.H., ed.; Inter American Copyright Union: New York, 1976.

21. Beebe, K. R.; Kowalski, B. R.; Anal. Chem. 1987, 59, 1007.

22. Bruns, R. E.; Faigle, J. F. G.; Quim. Nova 1985, 8, 84.

Received: February 9, 2006 Web Release Date: October 10, 2006 


\title{
Comparative Studies of the Sample Decomposition of Green and Roasted Coffee for Determination of Nutrients and Data Exploratory Analysis
}

\author{
Volnei R. Amorim Filho, ${ }^{*, a}$ Wagner L. Polito ${ }^{a}$ and José A. Gomes Neto ${ }^{b}$ \\ ${ }^{a}$ Instituto de Química de São Carlos, Universidade de São Paulo, CP 780, 13560-970 São Carlos-SP, Brazil \\ ${ }^{b}$ Departamento de Química Analítica, Instituto de Química, Universidade Estadual Paulista, CP 355, 14801-970 \\ Araraquara-SP, Brazil
}

Table S1. Concentrations of $\mathrm{K}, \mathrm{N}, \mathrm{Ca}, \mathrm{Mg}(\% \mathrm{~m} / \mathrm{m})$ and $\mathrm{Na}\left(\mathrm{mg} \mathrm{kg}^{-1}\right)$ in 35 coffee samples

\begin{tabular}{|c|c|c|c|c|c|}
\hline S. / Elem. & $\mathrm{Na}(10-174) *$ & $\mathrm{~K}(1.3816-3.7400) *$ & $\mathrm{~N}(1.9000-2.2500) *$ & $\mathrm{Ca}(0.0826-0.1310) *$ & $\operatorname{Mg}(0.1600-0.3000) *$ \\
\hline \multirow[t]{2}{*}{ PG 1} & $43.5 \pm 2.2(1)$ & $1.5138 \pm 0.0516(1)$ & $1.9855 \pm 0.0165(2)$ & $0.0932 \pm 0.0019$ & $0.2214 \pm 0.0029$ \\
\hline & $46.3 \pm 2.7(2)$ & $1.5019 \pm 0.0354$ & & $0.0822 \pm 0.0034$ & $0.2286 \pm 0.0025$ \\
\hline \multirow[t]{2}{*}{ PG 2} & $57.2 \pm 3.7(1)$ & $1.6350 \pm 0.0043$ & $2.1637 \pm 0.0376(2)$ & $0.1054 \pm 0.0004$ & $0.1914 \pm 0.0028$ \\
\hline & $60.9 \pm 1.0(2)$ & $1.5775 \pm 0.0022$ & & $0.0772 \pm 0.0106$ & $0.1984 \pm 0.0035$ \\
\hline \multirow[t]{2}{*}{ PG 3} & $58.1 \pm 3.5(1)$ & $1.6536 \pm 0.0371$ & $2.0181 \pm 0.0488$ & $0.0995 \pm 0.0009$ & $0.2016 \pm 0.0009$ \\
\hline & $45.6 \pm 2.6(2)$ & $1.5252 \pm 0.0019(2)$ & & $0.0843 \pm 0.0037(2)$ & $0.2017 \pm 0.0021$ \\
\hline \multirow[t]{2}{*}{ PG 4} & $53.0 \pm 1.6(1)$ & $1.5835 \pm 0.0141$ & $2.1897 \pm 0.0189(2)$ & $0.1172 \pm 0.0018$ & $0.1990 \pm 0.0012$ \\
\hline & $49.6 \pm 3.2(2)$ & $1.5383 \pm 0.0054$ & & $0.1034 \pm 0.0007$ & $0.1964 \pm 0.0027$ \\
\hline \multirow[t]{2}{*}{ PG 5} & $42.3 \pm 2.0(1)$ & $1.5246 \pm 0.0098$ & $2.2442 \pm 0.0348$ & $0.1049 \pm 0.0003$ & $0.2085 \pm 0.0016$ \\
\hline & $47.7 \pm 1.7(2)$ & $1.5199 \pm 0.0423$ & & $0.0788 \pm 0.0020$ & $0.2054 \pm 0.0010$ \\
\hline \multirow[t]{2}{*}{ PG 6} & $55.7 \pm 3.5(1)$ & $1.4967 \pm 0.0560$ & $1.9506 \pm 0.0132(2)$ & $0.1102 \pm 0.0078$ & $0.2020 \pm 0.0026$ \\
\hline & $67.0 \pm 2.8(2)$ & $1.5190 \pm 0.0163(2)$ & & $0.0881 \pm 0.0021$ & $0.2008 \pm 0.0026$ \\
\hline \multirow[t]{2}{*}{ PG 7} & $73.9 \pm 3.5(1)$ & $1.4802 \pm 0.0413$ & $1.8236 \pm 0.0142(2)$ & $0.1242 \pm 0.0025$ & $0.1861 \pm 0.0031$ \\
\hline & $74.7 \pm 7.7(2)$ & $1.4392 \pm 0.0507$ & & $0.0973 \pm 0.0052$ & $0.1868 \pm 0.0033$ \\
\hline \multirow[t]{2}{*}{ PG 8} & $70.7 \pm 2.1(1)$ & $2.1448 \pm 0.0361$ & $1.9194 \pm 0.0179$ & $0.1706 \pm 0.0043$ & $0.1609 \pm 0.0013$ \\
\hline & $75.5 \pm 2.6(2)$ & $2.0984 \pm 0.0400$ & & $0.1872 \pm 0.0037$ & $0.1598 \pm 0.0011$ \\
\hline \multirow[t]{2}{*}{ PG 9} & $42.8 \pm 2.3(1)$ & $1.5729 \pm 0.0031$ & $2.2285 \pm 0.0281$ & $0.1108 \pm 0.0010$ & $0.2043 \pm 0.0019$ \\
\hline & $52.0 \pm 1.4(2)$ & $1.6368 \pm 0.0054$ & & $0.1080 \pm 0.0007$ & $0.1935 \pm 0.0007$ (2) \\
\hline \multirow[t]{2}{*}{ PG 10} & $40.0 \pm 3.7(1)$ & $1.5740 \pm 0.0037$ & $2.1680 \pm 0.0652(2)$ & $0.0935 \pm 0.0023$ & $0.2066 \pm 0.0005$ \\
\hline & $47.8 \pm 4.3(2)$ & $1.6546 \pm 0.0077$ & & $0.0804 \pm 0.0010$ & $0.1913 \pm 0.0008$ \\
\hline \multirow[t]{2}{*}{ PG 11} & $37.3 \pm 0.3(1)$ & $1.6696 \pm 0.0102$ & $2.1315 \pm 0.0004$ & $2.1315 \pm 0.0004$ & $0.1999 \pm 0.0021$ \\
\hline & $59.5 \pm 1.9(2)$ & $1.8400 \pm 0.0215$ & & $0.0885 \pm 0.0002$ & $0.1778 \pm 0.0037$ \\
\hline \multirow[t]{2}{*}{ PG 12} & $53.9 \pm 1.1$ & $1.5277 \pm 0.0075$ & $2.2169 \pm 0.0535$ & $0.1192 \pm 0.0004$ & $0.1957 \pm 0.0020$ \\
\hline & $61.2 \pm 1.0(2)$ & $1.5497 \pm 0.0089$ & & $0.1055 \pm 0.0007$ & $0.1838 \pm 0.0004(2)$ \\
\hline \multirow[t]{2}{*}{ PG 13} & $55.3 \pm 3.5(1)$ & $1.5883 \pm 0.0227$ & $2.0279 \pm 0.0134$ & $0.0969 \pm 0.0008$ & $0.1911 \pm 0.0008$ \\
\hline & $51.0 \pm 0.1(2)$ & $1.6612 \pm 0.0086$ & & $0.0761 \pm 0.0007$ & $0.1798 \pm 0.0026$ \\
\hline \multirow[t]{2}{*}{ PG 14} & $54.1 \pm 1.6(1)$ & $1.5718 \pm 0.0071$ & $2.1244 \pm 0.0054$ & $0.1085 \pm 0.0014$ & $0.1948 \pm 0.0018$ \\
\hline & $59.3 \pm 1.3(2)$ & $1.5849 \pm 0.0091$ & & $0.1079 \pm 0.0009$ & $0.1838 \pm 0.0035$ \\
\hline \multirow[t]{2}{*}{ PG 15} & $41.8 \pm 2.4(1)$ & $1.7110 \pm 0.0085$ & $2.0564 \pm 0.0262$ & $0.0947 \pm 0.0009$ & $0.1905 \pm 0.0021$ \\
\hline & $46.9 \pm 2.7(2)$ & $1.6960 \pm 0.0099$ & & $0.0760 \pm 0.0002$ & $0.1855 \pm 0.0073$ \\
\hline \multirow[t]{2}{*}{ PG 16} & $49.6 \pm 3.5(1)$ & $1.6540 \pm 0.0020$ & $1.6423 \pm 0.0419(2)$ & $0.0885 \pm 0.0004$ & $0.1873 \pm 0.0008$ \\
\hline & $50.9 \pm 2.2(2)$ & $1.6213 \pm 0.0002$ & & $0.0834 \pm 0.0005$ & $0.1804 \pm 0.0013$ \\
\hline \multirow[t]{2}{*}{ PG 17} & $39.3 \pm 1.9(1)$ & $1.5869 \pm 0.0025$ & $2.1942 \pm 0.0026$ & $0.0893 \pm 0.0029$ & $0.1996 \pm 0.0014$ \\
\hline & $40.2 \pm 2.2(2)$ & $1.6301 \pm 0.0023$ & & $0.0732 \pm 0.0002$ & $0.1902 \pm 0.0011$ \\
\hline \multirow[t]{2}{*}{ PG 18} & $36.7 \pm 2.5(1)$ & $1.7604 \pm 0.0154$ & $2.1389 \pm 0.0629$ & $0.1023 \pm 0.0009$ & $0.1751 \pm 0.0003$ \\
\hline & $38.3 \pm 3.6(2)$ & $1.7776 \pm 0.0132$ & & $0.0986 \pm 0.0001$ & $0.1724 \pm 0.0013$ \\
\hline \multirow[t]{2}{*}{ PG 19} & $52.6 \pm 0.5(1)$ & $1.6237 \pm 0.0123$ & $2.0901 \pm 0.0580$ & $0.0928 \pm 0.0003$ & $0.1866 \pm 0.0018$ \\
\hline & $50.5 \pm 1.4(2)$ & $1.6025 \pm 0.0286$ & & $0.0944 \pm 0.0002$ & $0.1818 \pm 0.0068$ \\
\hline \multirow[t]{2}{*}{ PG 20} & $41.9 \pm 0.9(1)$ & $1.5967 \pm 0.0211$ & $2.3508 \pm 0.0035(2)$ & $0.0817 \pm 0.0008$ & $0.2016 \pm 0.0010$ \\
\hline & $55.5 \pm 1.2(2)$ & $1.5815 \pm 0.0248$ & & $0.0728 \pm 0.0007$ & $0.1946 \pm 0.0009$ \\
\hline FG 21 & $52.6 \pm 3.2(1)$ & $1.6275 \pm 0.0627$ & $2.3536 \pm 0.0468$ & $0.0807 \pm 0.0008$ & $0.1794 \pm 0.0074$ \\
\hline FG 22 & $30.4 \pm 0.7$ (1) & $1.5108 \pm 0.0858$ & $2.5731 \pm 0.0676$ & $0.0730 \pm 0.0015$ & $0.1598 \pm 0.0087$ \\
\hline
\end{tabular}

*e-mail: volfilho@gmail.com 
Table S1. cont.

\begin{tabular}{llllll}
\hline S. / Elem. & $\mathrm{Na}(10-174) *$ & $\mathrm{~K}(1.3816-3.7400) *$ & $\mathrm{~N}(1.9000-2.2500) *$ & $\mathrm{Ca}(0.0826-0.1310) *$ & $\mathrm{Mg}(0.1600-0.3000) *$ \\
\hline FG 23 & $47.9 \pm 3.4(1)$ & $1.4333 \pm 0.0033(1)$ & $2.1830 \pm 0.0422(2)$ & $0.0917 \pm 0.0007(1)$ & $0.1797 \pm 0.0034(1)$ \\
FG 24 & $46.8 \pm 2.1(1)$ & $1.4222 \pm 0.0582(1)$ & $2.0046 \pm 0.0184(2)$ & $0.1223 \pm 0.0016(1)$ & $0.2138 \pm 0.0030(1)$ \\
FG 25 & $43.7 \pm 2.5(1)$ & $1.4251 \pm 0.0328(1)$ & $2.1165 \pm 0.0729(2)$ & $0.1086 \pm 0.0015(1)$ & $0.1749 \pm 0.0048(1)$ \\
FG 26 & $54.5 \pm 3.1(1)$ & $1.4055 \pm 0.0715(1)$ & $2.1815 \pm 0.0628(2)$ & $0.1008 \pm 0.0032(1)$ & $0.1855 \pm 0.0099(1)$ \\
FG 27 & $45.6 \pm 0.1(1)$ & $1.5008 \pm 0.0953(1)$ & $2.2488 \pm 0.0010(2)$ & $0.0877 \pm 0.0031(1)$ & $0.1704 \pm 0.0059(1)$ \\
FG 28 & $47.6 \pm 3.7(1)$ & $1.5533 \pm 0.0093(1)$ & $2.3050 \pm 0.0177(2)$ & $0.0871 \pm 0.0008(1)$ & $0.1815 \pm 0.0027(1)$ \\
FG 29 & $51.8 \pm 2.8(1)$ & $1.5313 \pm 0.0161(1)$ & $2.3474 \pm 0.0400(2)$ & $0.1356 \pm 0.0137(1)$ & $0.1806 \pm 0.0017(1)$ \\
FG 30 & $43.5 \pm 2.4(1)$ & $1.2975 \pm 0.0411(1)$ & $2.2208 \pm 0.0589(2)$ & $0.1189 \pm 0.0039(1)$ & $0.1833 \pm 0.0072(1)$ \\
FG 31 & $51.8 \pm 2.6(1)$ & $1.7603 \pm 0.0173(1)$ & $2.1537 \pm 0.0121(2)$ & $0.0967 \pm 0.0005(1)$ & $0.1847 \pm 0.0084(1)$ \\
R 1 & $67.7 \pm 3.7(1)$ & $1.9633 \pm 0.0495(1)$ & $2.5210 \pm 0.0400(2)$ & $0.1121 \pm 0.0012(1)$ & $0.2236 \pm 0.0048(1)$ \\
& $96.0 \pm 8.5(2)$ & $2.1295 \pm 0.0276(2)$ & & $0.1390 \pm 0.0023(2)$ & $0.2194 \pm 0.0017(2)$ \\
R 2 & $85.3 \pm 1.5(1)$ & $2.6675 \pm 0.0241(1)$ & $2.1441 \pm 0.0302(2)$ & $0.1943 \pm 0.0031(1)$ & $0.1913 \pm 0.0003(1)$ \\
& $90.6 \pm 2.8(2)$ & $2.7930 \pm 0.0513(2)$ & & $0.1944 \pm 0.0020(2)$ & $0.1835 \pm 0.0021(2)$ \\
R 3 & $77.3 \pm 1.7(1)$ & $2.1120 \pm 0.0358(1)$ & $2.4487 \pm 0.0313(2)$ & $0.1243 \pm 0.0018(1)$ & $0.2335 \pm 0.0004(1)$ \\
& $111.9 \pm 3.5(2)$ & $2.0880 \pm 0.0325(2)$ & & $0.1200 \pm 0.0009(2)$ & $0.2283 \pm 0.0100(2)$ \\
R 4 & $80.6 \pm 7.1(1)$ & $2.3151 \pm 0.0754(1)$ & $2.1340 \pm 0.0392(2)$ & $0.1314 \pm 0.0054(1)$ & $0.2356 \pm 0.0028(1)$ \\
& $84.5 \pm 6.0(2)$ & $2.2698 \pm 0.0527(2)$ & & $0.1440 \pm 0.0048(2)$ & $0.2276 \pm 0.0040(2)$ \\
R 5 & $70.2 \pm 4.6(1)$ & $2.0433 \pm 0.0233(1)$ & $2.3406 \pm 0.0177(2)$ & $0.1219 \pm 0.0019(1)$ & $0.2222 \pm 0.0039(1)$ \\
& $100.1 \pm 4.2(2)$ & $2.0474 \pm 0.0486(2)$ & & $0.1335 \pm 0.0010(2)$ & $0.2165 \pm 0.0117(2)$
\end{tabular}

* found concentration values in literature; S. / Elem. - Sample / Element ;PG - Patrocínio/Minas Gerais green coffee; FG - Franca/São Paulo green coffee; $\mathrm{R}$ - Commercial soluble / roasted coffee; (1) microwave oven procedure; (2) digester heating block procedure. 
Table S2. Concentration of $\mathrm{Fe}, \mathrm{Mn}, \mathrm{Zn}$ and $\mathrm{Cu}\left(\mathrm{mg} \mathrm{kg}^{-1}\right)$ in 35 coffee samples

\begin{tabular}{|c|c|c|c|c|}
\hline S. / Elem. & $\mathrm{Fe}(25.0-140.0) *$ & $\operatorname{Mn}(14.0-60.0) *$ & $\mathrm{Zn}(1.00-10.00) *$ & $\mathrm{Cu}(1.0-33.0) *$ \\
\hline \multirow[t]{2}{*}{ PG 1} & $33.5 \pm 0.7$ (1) & $33.2 \pm 0.2(1)$ & $6.58 \pm 0.06$ & $14.2 \pm 0.2(1)$ \\
\hline & $31.6 \pm 0.9(2)$ & $33.1 \pm 0.4(2)$ & $6.61 \pm 0.10$ & $14.6 \pm 0.3(2)$ \\
\hline \multirow[t]{2}{*}{ PG 2} & $30.7 \pm 0.7$ (1) & $18.4 \pm 0.1(1)$ & $9.80 \pm 0.52$ & $15.5 \pm 0.4(1)$ \\
\hline & $28.2 \pm 0.2(2)$ & $18.4 \pm 0.2(2)$ & $9.77 \pm 0.30(2)$ & $15.2 \pm 0.2(2)$ \\
\hline \multirow[t]{2}{*}{ PG 3} & $30.2 \pm 0.4(1)$ & $13.7 \pm 0.1(1)$ & $10.45 \pm 0.13$ & $13.9 \pm 0.1$ \\
\hline & $28.2 \pm 0.5(2)$ & $13.8 \pm 0.1(2)$ & $10.73 \pm 0.17$ & $13.1 \pm 0.4(2)$ \\
\hline \multirow[t]{2}{*}{ PG 4} & $33.7 \pm 0.2$ & $28.2 \pm 0.2(1)$ & $7.48 \pm 0.56(1)$ & $15.5 \pm 0.2$ \\
\hline & $28.3 \pm 0.6(2)$ & $28.1 \pm 0.2(2)$ & $10.35 \pm 0.19(2)$ & $15.7 \pm 0.3(2)$ \\
\hline \multirow[t]{2}{*}{ PG 5} & $37.0 \pm 0.8$ & $31.0 \pm 0.4(1)$ & $6.17 \pm 0.07(1)$ & $14.3 \pm 0.3$ \\
\hline & $32.4 \pm 0.7(2)$ & $31.2 \pm 0.1(2)$ & $9.34 \pm 0.10$ & $14.9 \pm 0.3(2)$ \\
\hline \multirow[t]{2}{*}{ PG 6} & $42.2 \pm 1.1(1)$ & $14.7 \pm 0.1$ & $6.73 \pm 0.90$ & $14.5 \pm 0.3$ \\
\hline & $41.4 \pm 1.0(2)$ & $14.4 \pm 0.2(2)$ & $16.81 \pm 0.22$ & $14.0 \pm 0.2(2)$ \\
\hline \multirow[t]{2}{*}{ PG 7} & $107.5 \pm 4.7$ & $13.4 \pm 0.3$ & $7.81 \pm 0.37(1)$ & $14.3 \pm 0.6(1)$ \\
\hline & $97.9 \pm 5.2(2)$ & $16.2 \pm 0.2(2)$ & $9.67 \pm 0.24(2)$ & $14.0 \pm 0.7(2)$ \\
\hline \multirow[t]{2}{*}{ PG 8} & $107.0 \pm 3.4(1)$ & $23.6 \pm 0.1(1)$ & $5.89 \pm 0.41$ & $16.7 \pm 0.4$ \\
\hline & $78.7 \pm 4.8(2)$ & $23.5 \pm 1.0(2)$ & $13.64 \pm 0.55$ & $16.0 \pm 0.4(2)$ \\
\hline \multirow[t]{2}{*}{ PG 9} & $28.6 \pm 0.4(1)$ & $40.3 \pm 0.5$ & $4.29 \pm 0.07$ & $15.8 \pm 0.6$ \\
\hline & $28.3 \pm 0.3(2)$ & $41.1 \pm 0.2(2)$ & $6.9 \pm 0.1(2)$ & $15.4 \pm 0.2(2)$ \\
\hline \multirow[t]{2}{*}{ PG 10} & $28.0 \pm 0.6$ & $24.6 \pm 0,1(1)$ & $5.99 \pm 0.05$ & $15.5 \pm 0.1$ \\
\hline & $28.7 \pm 0.4(2)$ & $25.6 \pm 0,1(2)$ & $5.13 \pm 0.01$ & $15.4 \pm 0.2(2)$ \\
\hline \multirow[t]{2}{*}{ PG 11} & $26.8 \pm 0.7$ (1) & $24.0 \pm 0.4(1)$ & $4.24 \pm 0.06$ & $13.1 \pm 0.1$ \\
\hline & $25.8 \pm 0.5(2)$ & $24.1 \pm 0.2(2)$ & $4.55 \pm 0.03$ & $12.7 \pm 0.2$ \\
\hline \multirow[t]{2}{*}{ PG 12} & $30.2 \pm 0.4(1)$ & $21.6 \pm 0.4(1)$ & $6.2 \pm 0.5(1)$ & $15.5 \pm 0.6$ \\
\hline & $28.4 \pm 0.4(2)$ & $24.1 \pm 0.1$ & $5.5 \pm 0.1(2)$ & $13.5 \pm 0.3$ \\
\hline \multirow[t]{2}{*}{ PG 13} & $35.8 \pm 0.7$ (1) & $24.8 \pm 0.6$ & $7.2 \pm 0.4(1)$ & $14.6 \pm 0.4$ \\
\hline & $34.4 \pm 0.4(2)$ & $27.6 \pm 0.3(2)$ & $6.12 \pm 0.08$ & $13.6 \pm 0.1$ \\
\hline \multirow[t]{2}{*}{ PG 14} & $26.7 \pm 0.6$ & $19.2 \pm 0.3$ & $6.2 \pm 0.1(1)$ & $15.1 \pm 0.1$ \\
\hline & $24.0 \pm 0.5(2)$ & $19.7 \pm 0.2(2)$ & $6.28 \pm 0.08$ & $13.5 \pm 0.1(2)$ \\
\hline \multirow[t]{2}{*}{ PG 15} & $31.7 \pm 0.7(1)$ & $19.6 \pm 0.2(1)$ & $6.45 \pm 0.3$ & $16.6 \pm 0.1$ \\
\hline & $31.6 \pm 0.5(2)$ & $19.8 \pm 0.3(2)$ & $5.53 \pm 0.03$ & $16.2 \pm 0.1$ \\
\hline \multirow[t]{2}{*}{ PG 16} & $20.0 \pm 1.7(1)$ & $19.9 \pm 0.1(1)$ & $5.5 \pm 0.2(1)$ & $14.9 \pm 0.1$ \\
\hline & $25.7 \pm 1.1$ & $20.4 \pm 0.1$ & $4.2 \pm 0.1(2)$ & $14.5 \pm 0.1$ \\
\hline PG 17 & $31.7 \pm 0.3$ & $18.5 \pm 0.2$ & $4.01 \pm 0.5(1)$ & $16.6 \pm 0.2$ \\
\hline & $36.1 \pm 0.3(2)$ & $18.6 \pm 0.2(2)$ & $4.68 \pm 0.07(2)$ & $15.4 \pm 0.1$ \\
\hline PG 18 & $32.9 \pm 0.5$ & $22.1 \pm 0.1(1)$ & $4.64 \pm 0.06$ & $14.5 \pm 0.1$ \\
\hline & $34.5 \pm 0.5(2)$ & $22.6 \pm 0.1(2)$ & $5.78 \pm 0.03$ & $14.6 \pm 0.2(2)$ \\
\hline PG 19 & $28.3 \pm 0.8$ & $20.2 \pm 0.1(1)$ & $6.2 \pm 0.3(1)$ & $14.8 \pm 0.6(1)$ \\
\hline & $30.1 \pm 0.5(2)$ & $20.8 \pm 0.2(2)$ & $12.6 \pm 0.1(2)$ & $13.6 \pm 0.3(2)$ \\
\hline PG 20 & $33.7 \pm 2.8$ & $20.8 \pm 0.3(1)$ & $6.2 \pm 0.3$ & $16.1 \pm 0.1$ \\
\hline & $28.0 \pm 0.3(2)$ & $21.3 \pm 0.1(2)$ & $7.8 \pm 0.2(2)$ & $14.5 \pm 0.3(2)$ \\
\hline FG 21 & $31.3 \pm 0.5$ & $34.5 \pm 0.1$ (1) & $8.48 \pm 0.11$ & $16.4 \pm 0.2$ \\
\hline FG 22 & $442.0 \pm 3.5$ & $29.2 \pm 0.2(1)$ & $4.64 \pm 0.09$ & $14.0 \pm 0.2(1)$ \\
\hline FG 23 & $29.3 \pm 0.9(1)$ & $22.6 \pm 0.1$ & $7.56 \pm 0.11$ & $16.5 \pm 0.5$ \\
\hline FG 24 & $56.6 \pm 0.4$ & $22.8 \pm 0.1$ & $2.85 \pm 0.09$ & $14.2 \pm 0.2$ \\
\hline FG 25 & $27.6 \pm 0.2(1)$ & $18.8 \pm 0.4(1)$ & $5.84 \pm 0.19$ & $14.2 \pm 0.2(1)$ \\
\hline FG 26 & $27.5 \pm 0.6(1)$ & $28.5 \pm 0.1(1)$ & $3.79 \pm 0.02$ & $14.1 \pm 0.3$ \\
\hline FG 27 & $36.7 \pm 0.2$ & $27.8 \pm 0.1(1)$ & $6.41 \pm 0.08$ & $15.3 \pm 0.1$ \\
\hline FG 28 & $32.6 \pm 0.3(1)$ & $21.5 \pm 0.1(1)$ & $6.67 \pm 0.20$ & $14.0 \pm 0.1$ \\
\hline FG 29 & $39.7 \pm 0.4(1)$ & $30.1 \pm 0.1(1)$ & $7.46 \pm 0.14$ & $18.6 \pm 0.1$ \\
\hline FG 30 & $36.0 \pm 1.0$ & $31.8 \pm 0.1(1)$ & $8.61 \pm 0.07$ & $15.3 \pm 0.2(1)$ \\
\hline FG 31 & $29.2 \pm 0.4(1)$ & $18.6 \pm 0.3(1)$ & $6.96 \pm 0.11$ & $14.1 \pm 0.2(1)$ \\
\hline R 1 & $61.0 \pm 0.2$ & $22.0 \pm 1.0(1)$ & $7.14 \pm 0.33$ & $12.5 \pm 0.5$ \\
\hline & $51.4 \pm 2.1(2)$ & $19.8 \pm 0.9$ & $10.81 \pm 0.22$ & $13.3 \pm 0.2(2)$ \\
\hline $\mathrm{R} 2$ & $282.3 \pm 15.2$ & $27.4 \pm 0.1(1)$ & $7.08 \pm 0.34$ & $18.7 \pm 0.3$ \\
\hline & $192.0 \pm 5.2(2)$ & $26.4 \pm 0.4(2)$ & $12.76 \pm 0.51$ & $18.8 \pm 0.3(2)$ \\
\hline R 3 & $69.5 \pm 1.6(1)$ & $27.9 \pm 0.1$ & $4.65 \pm 0.42$ & $14.8 \pm 0.4$ \\
\hline & $51.7 \pm 1.7(2)$ & $26.2 \pm 1.3(2)$ & $5.23 \pm 0.44$ & $14.5 \pm 0.3$ \\
\hline R 4 & $233.7 \pm 2.2$ & $36.0 \pm 0.6(1)$ & $6.17 \pm 0.02$ & $17.1 \pm 0.3$ \\
\hline & $154.2 \pm 5.6(2)$ & $31.7 \pm 1.6(2)$ & $15.48 \pm 0.27$ & $18.1 \pm 0.2(2)$ \\
\hline R 5 & $85.0 \pm 8.5$ & $24.5 \pm 0.5(1)$ & $5.31 \pm 0.37(1)$ & $13.7 \pm 0.3$ \\
\hline & $66.7 \pm 1.8$ & $23.9 \pm 0.2$ & $4.80 \pm 0.32$ & $14.7 \pm 0.2$ \\
\hline
\end{tabular}

* found concentration values in literature; S. / Elem. - Sample / Element ;PG - Patrocínio/Minas Gerais green coffee; FG - Franca/São Paulo green coffee; $\mathrm{R}$ - Commercial soluble / roasted coffee; (1) microwave oven procedure; (2) digester heating block procedure. 